\title{
Ice-core net snow accumulation and seasonal snow chemistry at a temperate-glacier site: Mount Waddington, southwest British Columbia, Canada
}

\author{
Peter D. NEFF, ${ }^{1 *}$ Eric J. STEIG, ${ }^{1}$ Douglas H. CLARK, ${ }^{2}$ Joseph R. McCONNELL, ${ }^{3}$ \\ Erin C. PETTIT, ${ }^{4}$ Brian MENOUNOS ${ }^{5}$ \\ ${ }^{1}$ Department of Earth and Space Sciences, University of Washington, Seattle, WA, USA \\ E-mail: neff.peter@gmail.com \\ ${ }^{2}$ Department of Geology, Western Washington University, Bellingham, WA, USA \\ ${ }^{3}$ Division of Hydrologic Sciences, Desert Research Institute, Reno, NV, USA \\ ${ }^{4}$ Department of Geology and Geophysics, University of Alaska Fairbanks, Fairbanks, AK, USA \\ ${ }^{5}$ Geography Program, University of Northern British Columbia, Prince George, British Columbia, Canada
}

\begin{abstract}
A $141 \mathrm{~m}$ ice core was recovered from Combatant Col $\left(51.385^{\circ} \mathrm{N}, 1^{125.258}{ }^{\circ} \mathrm{W}\right.$; 3000 ma.s.l.), Mount Waddington, Coast Mountains, British Columbia, Canada. Records of black carbon, dust, lead and water stable isotopes demonstrate that unambiguous seasonality is preserved throughout the core, despite summer surface snowmelt and temperate ice. High accumulation rates at the site $\left(>4 \mathrm{~m}\right.$ ice eq. $\mathrm{a}^{-1}$ ) limit modification of annual stratigraphy by percolation of surface meltwater. The ice-core record spans the period 1973-2010. An annually averaged time series of lead concentrations from the core correlates well with historical records of lead emission from North America, and with ice-core records of lead from the Greenland ice sheet. The depth-age scale for the ice core provides sufficient constraint on the vertical strain to allow estimation of the age of the ice at bedrock. Total ice thickness at Combatant $\mathrm{Col}$ is $\sim 250 \mathrm{~m}$; an ice core to bedrock would likely contain ice in excess of $\mathbf{2 0 0}$ years in age. Accumulation at Combatant $\mathrm{Col}$ is significantly correlated with both regional precipitation and large-scale geopotential height anomalies.
\end{abstract}

\section{INTRODUCTION}

Numerous ice-core records have been obtained from polar ice sheets and high-altitude tropical glaciers, and are well known for the paleoclimate information they contain (e.g. Thompson and others, 1995; Taylor and others, 1997; Fisher and others, 1998; EPICA Community Members, 2004). Icecore records have also been obtained at mid-latitude sites, which provide information on local sources of anthropogenic and natural aerosols as well as records of regional climate that extend centuries beyond those provided by instrumental records (e.g. Schwikowski and others, 1999; Rupper and others, 2004; Thompson, 2004; Osterberg and others, 2008).

The number of mid-latitude sites suitable for ice cores is limited, and nearly all existing records have been retrieved from just two areas: the coastal ranges of Alaska and the Yukon, and the European Alps. Additionally, a number of records have been developed from lower-latitude sites on the Tibetan Plateau (e.g. Guliya, Dasuopu and Dunde sites (Thompson, 2000) and Qomolangma (Mount Everest; Kaspari and others, 2009)), but we do not discuss them here as they more closely resemble polar sites due to extremely high elevation. North American ice-core sites include the Eclipse Icefield and several sites in the vicinity of Mount Logan, Yukon, Canada (Yalcin and Wake, 2001; Shiraiwa and others, 2003; Fisher and others, 2008), BonaChurchill Col and Mount Wrangell, Alaska, USA (Yasunari and others, 2007; Urmann, 2009), and Fremont Glacier, Wyoming, USA (Naftz and others, 1996, 2002). Ice-core

*Present address: Antarctic Research Centre, Victoria University of Wellington, Wellington, New Zealand. sites in the European Alps include Fiescherhorn glacier (Schwikowski and others, 1999), Colle Gnifetti glacier (Thevenon and others, 2009) and Col du Dôme (Vincent and others, 1997; Preunkert and others, 2000).

Excluding Fremont Glacier, all of these ice cores were obtained from cold glaciers. Sub-freezing ice temperatures are generally assumed to be essential for preserving annual stratigraphy; the difficulty of obtaining reliable data from temperate glacier sites is frequently noted in the literature (Naftz and others, 1996; Koerner, 1997; Schotterer and others 1997, 2004; Steig, 2004). For example, Naftz and others (1996, 2002) retrieved a 250 year ice-core record from Fremont Glacier ( 4000 m a.s.l.) but did not demonstrate the preservation of annual layers. A $\sim 160 \mathrm{~m}$ long core was retrieved from South Cascade Glacier ( 2000 ma.s.l.), Washington, USA, but all chemical signals were even more markedly diffused by meltwater (J. Fitzpatrick, unpublished information). As a result of these difficulties, few ice cores have been obtained from temperate glaciers. Even at sites where the mean annual surface temperature is well below freezing, if summer surface melting occurs, infiltration of meltwater through the snow and firn may compromise or eliminate seasonal stratigraphy. However, once snowfall is transformed through firn to solid glacial ice, little further alteration should be expected, because ice is highly impermeable (Lliboutry, 1971). This suggests that at sites where surface melting occurs, the preservation of annual stratigraphy is primarily controlled by the extent of meltwater infiltration through the firn, rather than the temperature of the ice. Indeed, relatively undisturbed chemical stratigraphy has been observed even at extremely melt-affected sites: in the Lomonosovfonna (Svalbard) ice core, where melt presence is 


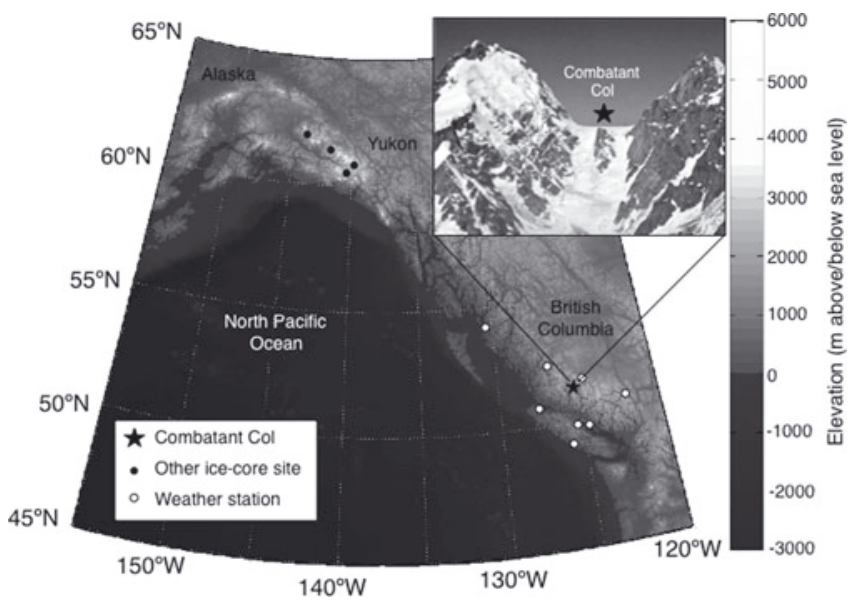

Fig. 1. Map location of Combatant Col drill site (starred), with inset picture showing local setting (photograph by E. Steig). Other ice cores and weather stations mentioned in the text are marked by black and white circles, respectively.

reported as high as $80 \%$, only certain acids were affected while isotopes and other chemical species remained immobile (Pohjola and others, 2002; Moore and others, 2005). Ice cores with intact annual stratigraphy may therefore be retrievable from temperate glaciers, provided the accumulation rate exceeds the infiltration depth. We test this hypothesis in the Coast Mountains of British Columbia, Canada, a region characterized by very high precipitation rates and a number of relatively high-elevation sites with ice thicknesses exceeding $200 \mathrm{~m}$. We report results of an ice core from Combatant $\mathrm{Col}\left(51.385^{\circ} \mathrm{N}, 125.258^{\circ} \mathrm{W} ; 3000 \mathrm{~m}\right.$ a.s.l.), which is a broad, nearly flat ice-covered saddle between Mount Waddington and Combatant Mountain in the Waddington Range, southern Coast Mountains (Figs 1 and 2).

\section{ICE-CORE COLLECTION AND ANALYSIS}

Ice at Combatant Col diverges and flows through two large icefalls, feeding ice to Tiedemann Glacier to the southeast

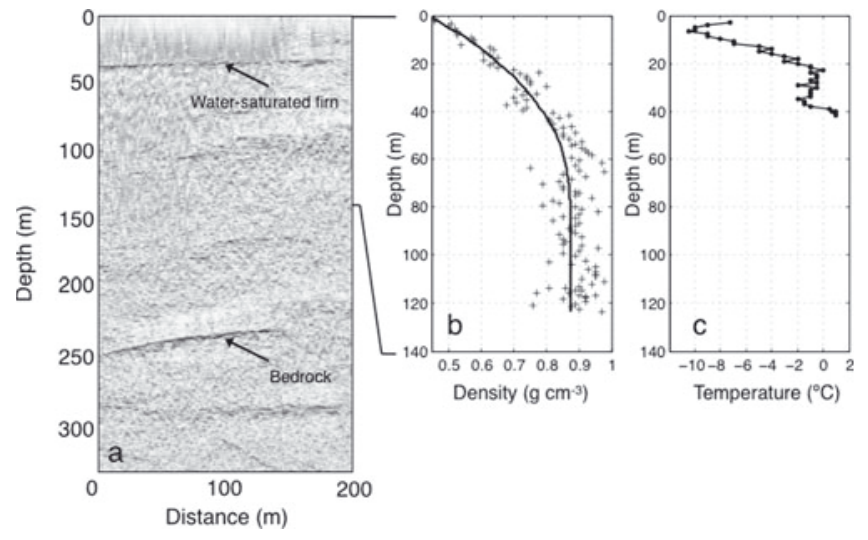

Fig. 3. (a) Radar data $(80 \mathrm{MHz}$ center frequency) from a $200 \mathrm{~m}$ transect across the Combatant Col drill site, trending roughly along the ice-flow divide (southwest-northeast). Arrows indicate the location of water-saturated firn, near $40 \mathrm{~m}$ depth, and a bedrock reflector at $\sim 250 \mathrm{~m}$. (b) Ice-core density measurements, made in the laboratory, fit with a third-order polynomial used to calculate ice-equivalent depths. The firn/ice transition at $0.83 \mathrm{~g} \mathrm{~cm}^{-3}$ occurs at $\sim 45 \mathrm{~m}$ depth. (c) Ice-core temperature, measured in the field, shows ice reaching $\sim 0^{\circ} \mathrm{C}$ at $40 \mathrm{~m}$ depth.

and Scimitar Glacier to the northwest (Fig. 2). A remote weather station maintained by the University of Northern British Columbia, located alongside Tiedemann Glacier $4 \mathrm{~km}$ southeast of and $1 \mathrm{~km}$ below Combatant Col, indicates a mean annual temperature of $-5^{\circ} \mathrm{C}$ at the ice-core site (assuming a wet adiabatic lapse rate of $7^{\circ} \mathrm{C} \mathrm{km}^{-1}$; P. Jackson, unpublished information). Firn temperature measured at $15 \mathrm{~m}$ depth also suggests a mean annual temperature of $-5^{\circ} \mathrm{C}$ (Fig. 3c), although this approximation may be of limited use due to the latent heating effect of meltwater (e.g. Pfeffer and Humphrey, 1996); it may therefore represent an upper limit on mean annual temperature or could simply be a remnant of lower winter temperatures (Paterson, 1994). Radar data collected in 2007 and 2010 indicate an ice thickness of $240 \pm 10 \mathrm{~m}$ (Fig. 3a). Preliminary coring at the site, conducted in September 2006 to $65 \mathrm{~m}$ depth, suggested high

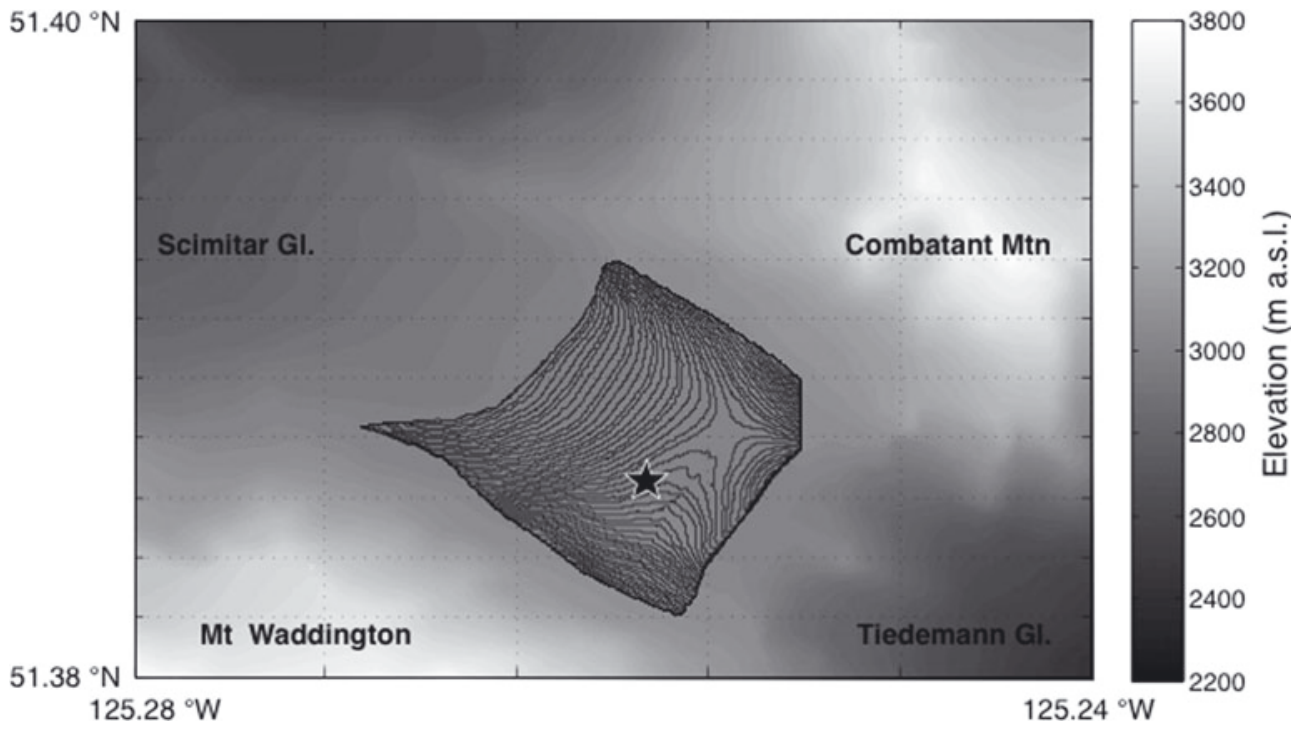

Fig. 2. Drill site (starred) detail and ice-surface topography. Grayscale shading derived from $20 \mathrm{~m}$ digital elevation map (DEM) data. Black contours are derived from GPS surveys conducted during field campaigns and are plotted with a $2 \mathrm{~m}$ contour interval. These new surfaceelevation data correct $20-40 \mathrm{~m}$ errors in the original $20 \mathrm{~m}$ DEM at Combatant Col. 
annual accumulation rates, and demonstrated preservation of seasonal cycles in soluble and insoluble chemical species throughout the firn and into the uppermost glacier ice. Data from this preliminary core, however, are discontinuous and thus not of sufficient quality for rigorous comparison with the new record described here (though we do report on water stable-isotope data from the upper $6 \mathrm{~m}$ of the 2006 core).

The $141 \mathrm{~m}$ Combatant Col ice core was drilled in July 2010 using the Ice Drilling and Design Office (IDDO) $10 \mathrm{~cm}$ diameter electromechanical drill (formerly called the 'PICO drill') to $55 \mathrm{~m}$ depth, and the IDDO $8 \mathrm{~cm}$ diameter electrothermal drill from 55 to $141 \mathrm{~m}$ (IDDO, 2011). Thermal drilling became necessary once the presence of water in the borehole prevented evacuation of drill chips in the electromechanical drill sonde. Ice temperature was measured with a thermal probe inserted into a small hole drilled in the side of each core section within 5 min of retrieval; ice at the site was between $-3^{\circ} \mathrm{C}$ and $0^{\circ} \mathrm{C}$ at depths below $20 \mathrm{~m}$ (Fig. 3c), with consistent temperatures of $0 \pm 1^{\circ} \mathrm{C}$ below $40 \mathrm{~m}$. The region of transition from cold to temperate ice is clearly visible in the radar stratigraphy at $40 \mathrm{~m}$ depth (Fig. 3a), likely due to the water-saturated nature of the firn below this depth. The firn/ice transition at $0.83 \mathrm{~g} \mathrm{~cm}^{-3}$ occurs at $\sim 45 \mathrm{~m}$ depth (Fig. 3b), based on density measured by weighing samples of each $\sim 1 \mathrm{~m}$ core section (see below). Freezing of water in the borehole below $80 \mathrm{~m}$ depth resulted in partial closure of the borehole over hour- to day-long periods. During one 48 hour drilling shutdown period, for example, a $2 \mathrm{~cm}$ thick annulus of ice developed on the borehole wall. Despite efforts to ensure consistent delivery of ethanol past the porous firn layers and to mix water and ethanol in the borehole, ice freeze-on stalled drilling progress at $118 \mathrm{~m}$. Our attempts to continue drilling required diversion of the borehole at $113.5 \mathrm{~m}$ depth, as variance in drill-tower leveling made reopening and following the existing borehole impossible. The divergent borehole, with a deflection of $2-3^{\circ}$ from the vertical, reached a final depth of $141 \mathrm{~m}$, after a second diversion at $124 \mathrm{~m}$. We collected overlapping sections of ice at both borehole diversions, in order to recover accurate depth information that was lost when continuous ice-core collection was interrupted. Matching of chemical stratigraphy allowed for recovery of absolute depth correct to within a few centimeters. No further progress could be made below $141 \mathrm{~m}$ due to continued refreezing of water in the borehole, leaving $\sim 100 \mathrm{~m}$ of ice between the final ice-core depth and the bedrock below.

In the field, we measured, photographed and placed $1 \mathrm{~m}$ ice-core sections into high-density polyethylene (HDPE) bags. The cores were stored in a covered snow pit for up to 4 days, then taken by a $\sim 30$ min helicopter flight to a freezer truck. At the end of the drilling season, we shipped the ice to storage facilities at the University of Washington, Seattle. In November 2010, we transported the core sections to the US National Ice Core Laboratory, Denver, Colorado, for sampling and allocation to laboratories. Core sections were cut into five parallel longitudinal samples: a center core sample $(3.5 \mathrm{~cm} \times 3.5 \mathrm{~cm} \times 1 \mathrm{~m})$ for chemical measurements, a side sample for water stable-isotope analysis, and several archive samples. Immediately prior to sampling, a slab of ice from the center of each core section was planed and scanned using a high-resolution digital imaging system (McGwire and others, 2008). We analyzed melt layers in the ice core by averaging the grayscale pixel intensity of the approximate longitudinal center line from every core section image taken. This record of pixel intensity clearly demarks transparent, bubble-free melt features as dark horizons, due to the black background and overhead lighting of the imaging system. Melt-free winter snow and firn scatters the overhead lighting and appears bright.

We sampled the ice core continuously from the surface snow $(0 \mathrm{~m})$ to the deepest ice $(141 \mathrm{~m})$. Center core samples were analyzed at the Desert Research Institute (DRI) using a continuous-flow system (McConnell and others, 2002, 2007). In this method, ice samples are melted vertically using a sectioned heating element, isolating the innermost ice from the sample and discarding contaminated outer surfaces. The DRI system employs two high-resolution inductively coupled plasma mass spectrometers for elemental determinations, laser-based instruments for measurements of black carbon and insoluble dust particle concentrations and size distributions, and a range of fluorimeters and spectrophotometers for chemical measurements. This instrumentation yields $<1 \mathrm{~cm}$ effective depth resolution measurements. Results from the black-carbon, lead and dust measurements, which all exhibit high-amplitude variability throughout the ice core, are discussed in this paper. Dust data presented here represent particle sizes of $2.4-4.5 \mathrm{~nm}$. We also obtained sulfur and acidity measurements, which have been successfully used to detect volcanic events at other sites (e.g. Yalcin and others, 2007). Unfortunately the sulfur record provides no evidence of distinct peaks that can be correlated either with known volcanic events or sulfur peaks from other ice-core records in Alaska and the Yukon. Additionally, concerns about contamination of this record in some sections of the core preclude interpretation of any potential events. We measured the density $( \pm 10 \%)$ of each $3.5 \mathrm{~cm}$ $\times 3.5 \mathrm{~cm} \times \sim 1 \mathrm{~m}$ core sample, by weighing and measuring dimensions of the ice samples. A density-depth profile estimated from these data using a third-order polynomial fit (Fig. 3b) is used to calculate the ice-equivalent depth and thicknesses of annual layers in the ice core.

At the University of Washington stable-isotope laboratory, we cut 1416 samples at $\sim 10 \mathrm{~cm}$ resolution for the length of the core, to be used for water stable-isotope $\left(\delta^{18} \mathrm{O}\right.$ and $\left.\delta \mathrm{D}\right)$ analysis. Each sample was melted, decanted into a $20 \mathrm{~mL}$ HDPE bottle and refrigerated until analysis. Measurements of $\delta^{18} \mathrm{O}$ and $\delta \mathrm{D}$ were made simultaneously for each sample using a Picarro cavity ring-down laser spectrometer. We present water stable isotopes in the classical $\delta$ notation as defined by Dansgaard (1964), reporting values relative to Vienna Standard Mean Ocean Water (VSMOW) and normalized to the VSMOW/SLAP (Standard Light Antarctic Precipitation) scale (e.g. Gonfiantini, 1978).

\section{SEASONALITY IN CHEMICAL RECORDS}

Chemical peaks within the Combatant Col ice core, coincident in black carbon, dust, lead and water stable isotopes, occur in sections of core with higher incidence of melt layers. This relationship is most obvious in the snow and firn portions of the core $(0-40 \mathrm{~m})$ where melt layers are most easily quantified, and chemical peaks do not appear to be preferentially concentrated in individual melt layers. Melt layers in the snow and firn section of the core constitute $\sim 7 \%(\sim 2.8 \mathrm{~m})$ of the total thickness. An example annual sequence is shown in Figure 4. Black-carbon concentrations in the core range from 0 to $23.94 \mathrm{ppb}(2.4 \mathrm{ppb}$ standard deviation (SD)), while minima typically range from 0.1 to 


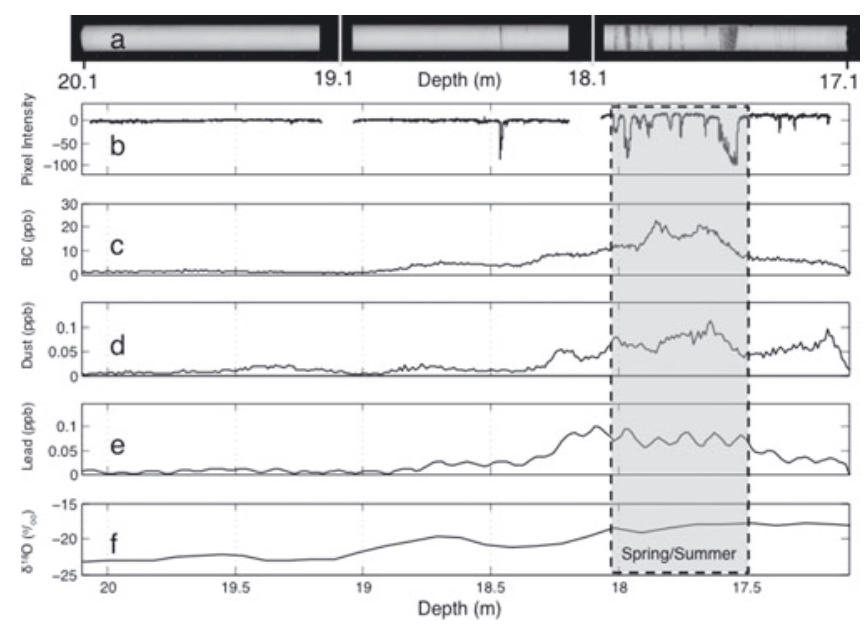

Fig. 4. Example section from 17 to $20 \mathrm{~m}$ depth in the Combatant Col ice core, depicting seasonality in records of (a) visual appearance, (b) image pixel intensity (melt layers), (c) black carbon (BC), (d) dust, (e) lead and (f) $\delta^{18} \mathrm{O}$. All data show lower concentrations/ values during winter, gradually increasing to a spring/summer maximum, highlighted by gray box.

$1.0 \mathrm{ppb}$. Dust concentrations range from 0 to $0.68 \mathrm{ppb}$ (0.03 ppb SD), and show several extremely large peaks with concentrations up to $0.4 \mathrm{ppb}$, while other maxima are as low as $0.05 \mathrm{ppb}$. Dust minima are $<0.02 \mathrm{ppb}$ in all cases. The record of lead from Combatant Col ranges from 0 to $2.65 \mathrm{ppb}(0.11 \mathrm{ppb} \mathrm{SD})$. Maximum concentrations are observed in the deepest $20 \mathrm{~m}$ of the core (121-141 m), with peaks as high as $2 \mathrm{ppb}$ and typical peak values of $0.5 \mathrm{ppb}$, compared to peak values of $\leq 0.4 \mathrm{ppb}$ in the upper $120 \mathrm{~m}$. Stable-isotope concentrations $\left(\delta^{18} \mathrm{O}\right)$ vary from more negative values $(-25 \%$ to $-22 \%$ ) in the melt-free portion, to less negative $(-18 \%$ o to $-14 \%$ ) in the melt-rich snow and ice. None of the chemical signals reported here show significant changes in character at or below the firn/ice transition observed at $40-45 \mathrm{~m}$ depth, indicating that meltwater alteration of these signals is limited even as they pass through this water-saturated zone.

We interpret the pattern observed in black-carbon, dust and lead measurements as follows. Because maximum precipitation in coastal British Columbia occurs from October to March (1971-2000 climatology; Environment Canada, 2011), we interpret the base of the sequence in Figure 4 as a unit of snow deposited during these winter months. The increasingly impurity-rich upper portion of this snow sequence indicates the gradual addition of impurities to the developing snowpack, coincident with spring and summer months of warmer surface air and maximum transPacific dust and pollutant fluxes from Asia (Merrill and others, 1989; Bey and others, 2001). Individual trans-Pacific transport events have been observed with diverse compositions; sometimes with components exclusively of industrial origin, though more often they comprise mixes of industrial emission and mineral dust sources (Jaffe and others, 2003). Local contributions of these aerosols are likely also important, considering that a major metropolitan center (Vancouver) is only $280 \mathrm{~km}$ distant. Local forest fires may also contribute to the seasonal maximum in black carbon. Finally, occasional storm activity during summer deposits small amounts of snow with high impurity content and less negative $\delta^{18} \mathrm{O}$ and $\delta \mathrm{D}$ values. The seasonality in isotopes is consistent with data compiled by Bowen (2008) from the International Atomic Energy Agency (IAEA)/World Meteorological Organization (WMO) global network for isotopes in precipitation (GNIP) stations and other sources, showing that there is strong seasonality in water isotopes along coastal British Columbia.

Maximum temperatures during summer months (JuneAugust) partially melt surface snow layers, which were deposited in winter and spring, and meltwater from these layers penetrates the snowpack. Due to exceptionally high accumulation rates at Combatant Col, this meltwater evidently penetrates only part-way through an annual layer. Thus, the seasonal cycle of water stable-isotope values and impurity concentrations is preserved. This interpretation of spring/summer stratigraphic horizon formation is the basis for our annual dating of the ice core.

\section{DATING}

Dating of the core was performed iteratively, by adding independent datasets sequentially after counting subjectively determined annual peaks. The visual, geochemical and isotope stratigraphy are plotted versus the final age scale in Figure 5. Initial age scales were developed using the records of melt layers, black carbon and dust only. Visual analysis of melt layers was helpful in dating the snow and firn section of the core, showing that closely spaced highconcentration excursions represent individual spring/summer aerosol deposition events (Figs 4 and 5a). For depths below $40 \mathrm{~m}$, quantitative visual analysis was not as useful because of reduced contrast between melt layers and meltfree glacier ice (see Fig. 5a).

The records of black carbon and dust (Fig. 5b and c) provided a preliminary age scale for the entire core, but there is some ambiguity in certain sections of these records. For this reason, incorporating lead into the dating scheme proved valuable, as extremely low background values of lead provide an independent marker for winter snow (Fig. 5d). Additionally, the dated lead time series corresponds well with known histories of lead emissions from North America, giving us confidence in the accuracy of our dating. The significantly elevated lead concentrations in the deepest $20 \mathrm{~m}$ of the core correspond with the 1970s, when use of leaded gasoline in the USA and Canada was near its maximum. Subsequent regulation by both countries halved the amount of lead in gasoline in 1982, and eliminated it altogether by the early 1990s (Legrand and Mayewski, 1997; Bülhofer and Rosman, 2001). This decrease in lead is clearly observed at Combatant Col, with concentrations sharply dropping off in the early 1980s and remaining low through the 1990s.

We compare the lead records from four sites: Combatant Col (Fig. 6a), southwest Greenland ACT2 (Fig. 6a; McConnell and Edwards, 2008), Greenland Summit (Fig. 6a; J. McConnell, unpublished information) and Mount Logan ProspectorRussell (PR) Col (Fig. 6b; Osterberg and others, 2008). The Combatant Col lead record correlates well with both the Greenland ACT2 and Greenland Summit lead records, at $>95 \%$ significance (Table 1). All significance levels presented account for autocorrelation following Bretherton and others (1999). Lead-isotope data indicate that North America is the dominant source of lead in Greenland (Rosman and others, 1994). That the Combatant Col lead record compares favorably with Greenland suggests that lead 


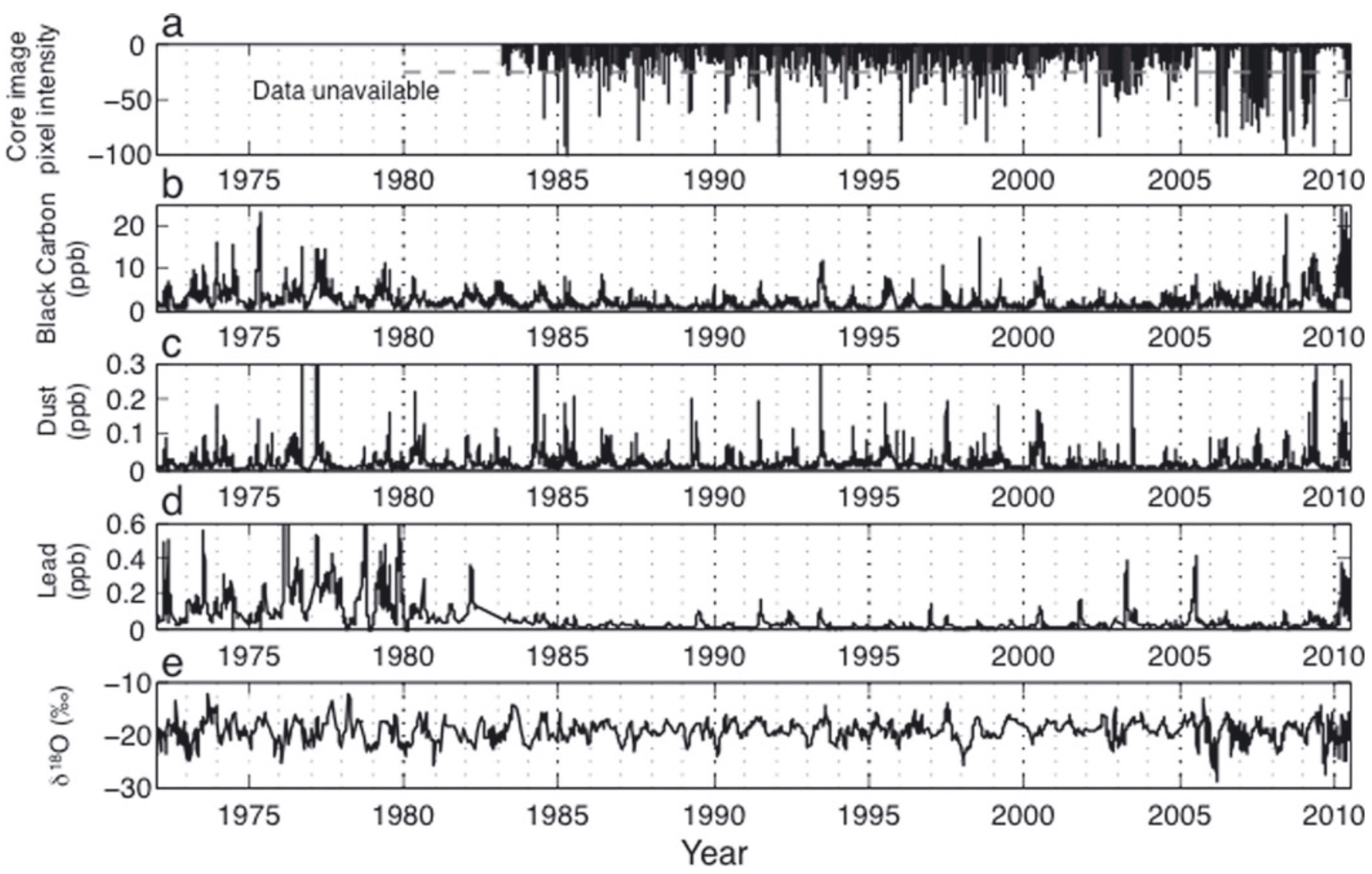

Fig. 5. Core image pixel intensity (a), black carbon (b), dust (c), lead (d) and $\delta^{18} \mathrm{O}(\mathrm{e})$ in the Combatant Col ice core, plotted versus year. Core image pixel intensity is a measure of melt content derived from image brightness More negative values in (a) are dark melt layers which transmit the overhead lighting of the scanner; less negative values are lighter snow or bubbly glacier ice which scatter the overhead lighting of the scanner. A horizontal dashed line has been added to clearly demark melt layers with strongly negative (dark) values.

aerosol deposited at Combatant Col is primarily North American in source, and also indicates our dating of the ice core is accurate. The Combatant Col lead record shows no significant correlation with that of Mount Logan, where large peaks in lead concentration are observed during the 1980s, and increasing concentrations are observed up to the most recent years of the record (see Fig. 6; Table 1). This history of lead deposition at Mount Logan has been interpreted as largely of Asian origin, due to later industrialization and less stringent regulation of pollution than in North America (Osterberg and others, 2008).

Water stable isotopes, $\delta^{18} \mathrm{O}$ and $\delta \mathrm{D}$, were the final component included in our multi-parameter dating of the Combatant $\mathrm{Col}$ ice core. For the purposes of dating, $\delta^{18} \mathrm{O}$ and $\delta D$ are nearly identical, so we report only $\delta^{18} \mathrm{O}$ here (Fig. 5e). The initial timescales, based on visual and chemical stratigraphy only, agree well with the $\delta^{18} \mathrm{O}$ data. Due to the thick annual layers at Combatant Col, the relatively coarse $10 \mathrm{~cm}$ sampling for water stable-isotope measurements results in an average of 35 samples per year. Data from surface snow and firn cores drilled at the site in 2006 provide additional, definitive validation for our dating of the most recent 5 years of the 2010 ice core (Fig. 7). In the 2006 core, the top of which represents the snow surface during summer of that year, we see anomalously negative $\delta^{18} \mathrm{O}$ values $(-30 \%) 2.3 \mathrm{~m}$ below the surface, deposited during winter 2005/06 or spring 2006. This same 2006 annual layer from the more recent and longer Combatant Col ice core, now buried at $\sim 36 \mathrm{~m}$ depth, exhibits nearly identical minimum values, the most negative of the entire record. We are confident that these are the same annual layer, and we further note that the $\delta^{18} \mathrm{O}$ values are well preserved at depth,

Table 1. Correlation, $r$, and significance, $p$, between annual Combatant Col lead record and other ice-core lead records. Correlations with $>95 \%$ significance are in bold

\begin{tabular}{|c|c|c|c|c|c|}
\hline \multirow[t]{2}{*}{ Ice core } & Coordinates & Elevation & $\begin{array}{c}\text { Record length } \\
\text { (used in correlations) }\end{array}$ & $\begin{array}{c}\text { Combatant } \mathrm{Col} \mathrm{Pb} \\
\text { correlation, } r\end{array}$ & Significance, $p$ \\
\hline & & ma.s.l. & & & \\
\hline $\mathrm{ACT} 2$ & $66.0^{\circ} \mathrm{N}, 45.2^{\circ} \mathrm{W}$ & 2410 & 1973-2002 & 0.82 & $<0.02$ \\
\hline Summit & $72.6^{\circ} \mathrm{N}, 38.5^{\circ} \mathrm{W}$ & 3210 & 1973-2009 & 0.62 & $<0.02$ \\
\hline Mount Logan (PR Col) & $60.6^{\circ} \mathrm{N}, 140.6^{\circ} \mathrm{W}$ & 5300 & 1973-98 & -0.25 & 0.21 \\
\hline
\end{tabular}



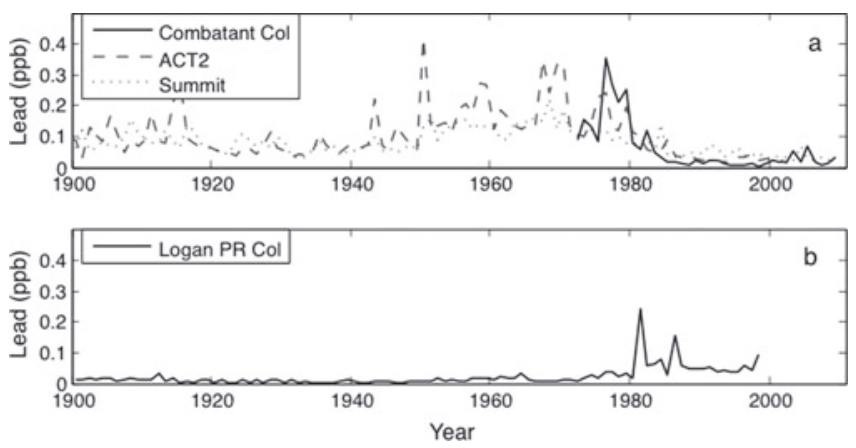

Fig. 6. Comparison between Combatant Col annual lead concentrations ( $\mathrm{a}$; black line) and ice-core lead records from the Greenland ice sheet (a; dotted and dashed lines) and Mount Logan PR Col (b). Both the Combatant Col and Greenland ACT2 (dashed lines) and Summit (dotted line) records show high lead concentrations in the 1970s, followed by sharp decreases in concentration in the early 1980s. In contrast, lead concentrations at Mount Logan show a steady rise from the 1970s to the most recent years of the record. See Table 1 for location and correlation details.

showing no evidence of alteration of the original surface layers deposited in 2006 through the subsequent 4 years. This finding is significant, because alteration of water stable isotopes, including diminished seasonality and an overall decrease in summertime values, is commonly observed even at cold glacier sites (e.g. Koerner, 1997; Moran and Marshall, 2009). In the Combatant Col core, we observe seasonal isotope variation of roughly constant amplitude throughout the record, including in the deepest ice.

\section{ANNUAL-LAYER THICKNESS AND ICE-FLOW CORRECTIONS}

Annual-layer thicknesses from the Combatant Col ice core (Fig. 8) indicate extremely thick snow-and-ice sequences from the most recent (and least flow-altered) layers at the site, up to $12 \mathrm{~m}$ at the thickest $(\sim 8.3 \mathrm{~m}$ ice eq.). These layers gradually thin with depth, due to ice flow, to reach annuallayer thicknesses of 1-2 $\mathrm{m}$ ice eq. at depths below $\sim 100 \mathrm{~m}$. We calculate uncertainties in layer thickness by considering the standard error of the thicknesses from four sequentially developed age scales.

To obtain annual accumulation rates, we correct annual-layer thicknesses for dynamic thinning using the

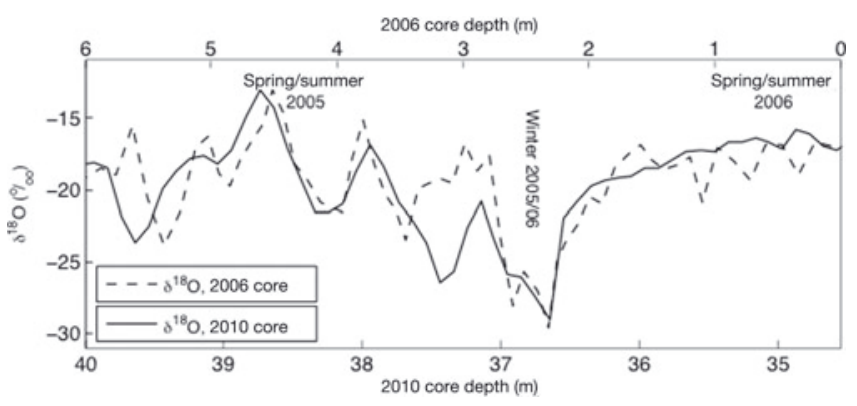

Fig. 7. Comparison of $\delta^{18} \mathrm{O}$ in the 2006 and 2010 cores. The nearly identical extreme minimum in $\delta^{18} \mathrm{O}$, dated independently as winter 2005/06, demonstrates the preservation of seasonality through firn and into ice.

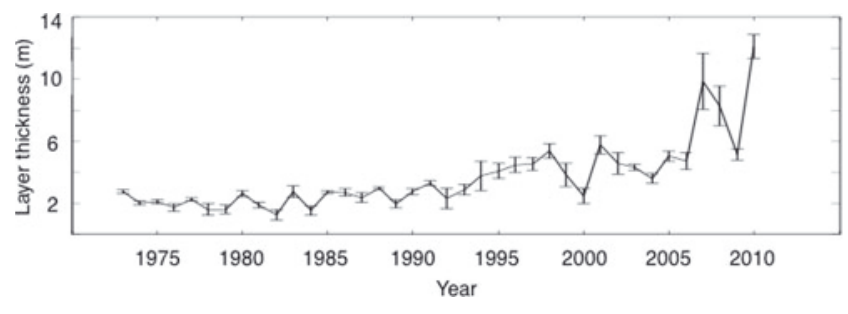

Fig. 8. Raw annual-layer thickness from the Combatant Col ice-core record. Error bars indicate \pm 1 SD calculated from four age scales.

one-dimensional ice-flow model of Dansgaard and Johnsen (1969). This model uses a simple piecewise-linear approximation of the horizontal-velocity profile, assumed to have a constant velocity equal to that of the surface, $u_{\mathrm{s}}$, down to some distance $h$ above the bed, and then decreasing linearly towards a value $u_{\mathrm{b}}$, the sliding velocity, at the bed. The depth-age relation for constant accumulation and steadystate flow is given as follows, where $H$ is the total ice thickness, $\dot{b}$ is the surface accumulation rate, $u_{\mathrm{s}}$ is the surface velocity and $z$ is the distance above the bed:

$$
\begin{aligned}
& \text { for } z>h: \quad t(z)=\frac{H}{u_{\mathrm{s}} \dot{b}}\left(\ln \frac{h\left(u_{\mathrm{b}}-u_{\mathrm{s}}\right)+2 u_{\mathrm{s}} z}{h\left(u_{\mathrm{b}}-u_{\mathrm{s}}\right)+2 u_{\mathrm{s}}}\right) \\
& \text { for } z=h: \quad t(z)=\frac{2 H}{u_{\mathrm{s}} \dot{b}} \ln \left(\frac{\left(u_{\mathrm{b}}-u_{\mathrm{s}}\right) h+2 u_{\mathrm{s}} h}{\left(u_{\mathrm{b}}-u_{\mathrm{s}}\right) h+2 u_{\mathrm{s}}}\right)
\end{aligned}
$$

for $z<h, u_{\mathrm{b}}>0$ :

$$
\begin{aligned}
t(z)= & t(h) \\
& +\frac{H}{u_{\mathrm{b}} \dot{b}}\left(\ln \frac{z}{\left(u_{\mathrm{b}}-u_{\mathrm{s}}\right) z-2 u_{\mathrm{b}} h}-\ln \frac{h}{\left(u_{\mathrm{b}}-u_{\mathrm{s}}\right) h-2 u_{\mathrm{b}} h}\right) ;
\end{aligned}
$$

and for $z<h, u_{\mathrm{b}}=0: \quad t(z)=\frac{2 H}{u_{\mathrm{s}} \dot{b}}\left(1-\frac{h}{z}\right)$.

Assuming there is no long-term trend in accumulation rate no significant trends are observed in regional weather station precipitation records (Environment Canada, 2011) during the time period overlapping the ice-core record - we can estimate the parameter $h$ and the ratio $u_{\mathrm{b}} / u_{\mathrm{s}}$ by minimizing the difference between the calculated and observed age-depth relationship over a range of plausible values of surface accumulation rate $\dot{b}$ and total ice thickness $H$. That is, we minimize the root-mean-square $(\mathrm{rms})$ difference $\sqrt{\sum\left(t_{\mathrm{m}}(z)-t(z)\right)^{2}}$, where $t_{\mathrm{m}}$ is the measured timescale and $t$ is the calculated timescale at ice-equivalent heights $z$ (Fig. 9a). Note that although it is virtually certain that there is melting at the bed, it is negligible in this setting even at very high geothermal heat flux, because the surface accumulation rate is so high. For example, a geothermal heat flux of $120 \mathrm{~mW} \mathrm{~m}^{-2}$, about twice the regional average (e.g. Lewis and others, 1985), would result in basal melt rates of order only $1 \mathrm{~cm} \mathrm{a}^{-1}$ (e.g. Paterson, 1994).

The results show that lowest rms values are found with $\dot{b} \sim 7 \mathrm{~m} \mathrm{a}^{-1}$ and $H \sim 240 \mathrm{~m}$ ice eq., both consistent with the observations. Optimal values of $h / H$ and $u_{\mathrm{b}} / u_{\mathrm{s}}$ are $h /$ $H \sim 0.6-0.7, u_{\mathrm{b}} / u_{\mathrm{s}}<0.1$ (Fig. 9a), consistent with typical values for flow near an ice divide (Waddington and others, 2001). We note that somewhat lower rms values can be obtained for $\dot{b}=8 \mathrm{~m} \mathrm{a}^{-1}$ and $H=260 \mathrm{~m}$, if $h / H>0.9$. However, $H>250 \mathrm{~m}$ is unlikely on the basis of the radar data 

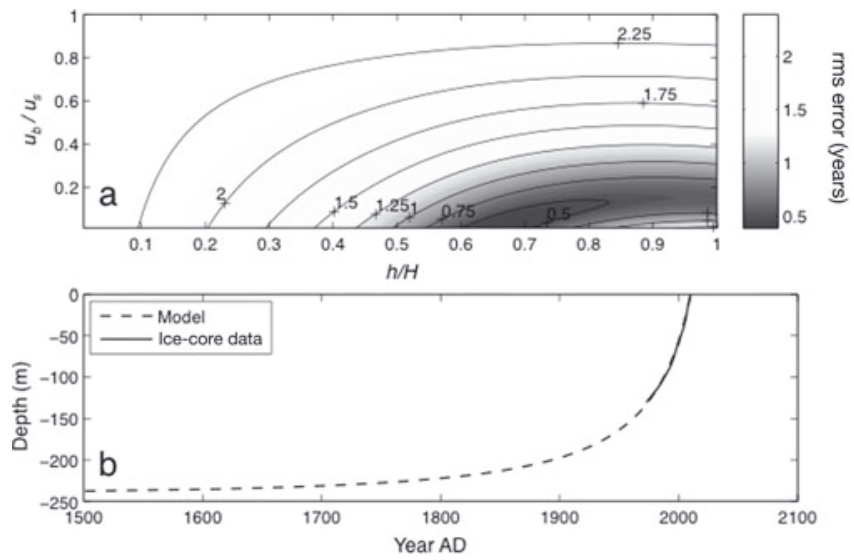

Fig. 9. (a) Root-mean-square difference between measured depthage relationship for the Combatant Col core and that calculated with a Dansgaard-Johnsen flow model for all possible values of $h / H$ and of $u_{\mathrm{b}} / u_{\mathrm{s}}\left(\dot{b}=7 \mathrm{~m} \mathrm{a}^{-1}\right.$ and $\left.H=240 \mathrm{~m}\right)$. (b) Measured and modeled depth-age relationships, using $u_{\mathrm{b}} / u_{\mathrm{s}}=0, h / H=0.65, \dot{b}=7 \mathrm{~m} \mathrm{a}^{-1}$ and $H=240 \mathrm{~m}$.

(Fig. 3a). Basal sliding rates greater than $u_{\mathrm{b}} / u_{\mathrm{s}}=10 \%$ would also require ice thicknesses that are likely ruled out by the radar data, strongly indicating that basal sliding is a small fraction of the total ice velocity. In any case, corrections to the annual-layer thickness using a range of plausible choices are essentially identical to those for $\dot{b}=7 \mathrm{ma}^{-1}$ and $H=240 \mathrm{~m}$, because higher accumulation rates and/or high sliding rates require greater thinning at depth (and therefore a greater value of $h / H$ ) to be consistent with the observations. Conversely, low values of accumulation rate imply smaller values of $H$ and $h / H$. However, depths less than $230 \mathrm{~m}$ are inconsistent with the observed depth-age relationship, regardless of the values of $h / H$ and $u_{\mathrm{b}} / u_{\mathrm{s}}$ used. We conclude that the observed depth-age relationship strongly constrains the layer-thinning profile with depth, allowing us to convert the measured layer thicknesses to original annual accumulation rates at the surface. For simplicity, we use $\dot{b}=7 \mathrm{ma}^{-1}, h / H=0.65, H=240 \mathrm{~m}$ and $u_{\mathrm{b}} / u_{\mathrm{s}}=0$. Figure $9 \mathrm{~b}$ compares the calculated timescale for these parameters with the observed depth-age profile from the Combatant Col ice core. Note that the implied age at depth is well in excess of 200 years; we discuss the implications of this for future work below.

The time series of ice flow-corrected net annual accumulation from Combatant $\mathrm{Col}$ is shown in Figure 10. We estimate uncertainty in the accumulation data by taking into account the estimated uncertainty in the timescale, based on the sequence of four depth-age relationships developed iteratively as individual stratigraphic time series (i.e. records of melt layers, geochemistry, isotopes) were incorporated into our multi-parameter dating (described in Section 4). This translates to an average uncertainty of $\sim 12 \%$ in accumulation for each year, or, equivalently, an age uncertainty of $\sim 1$ year. Maximum annual accumulation rates of $10-11 \mathrm{~m}$ ice eq $\mathrm{a}^{-1}$ are observed, with minima no lower than $\sim 4 \mathrm{ma}^{-1}$. Annual accumulation rates of this magnitude, averaging $6.8 \mathrm{ma}^{-1}$ over this 38 year record, place Combatant Col among the wettest places on Earth (NCDC, 2008). In contrast, leeward climate stations on Vancouver Island only average annual precipitation of 1.0$1.5 \mathrm{~m} \mathrm{a}^{-1}$ from 1971 to 2000 (Environment Canada, 2011).

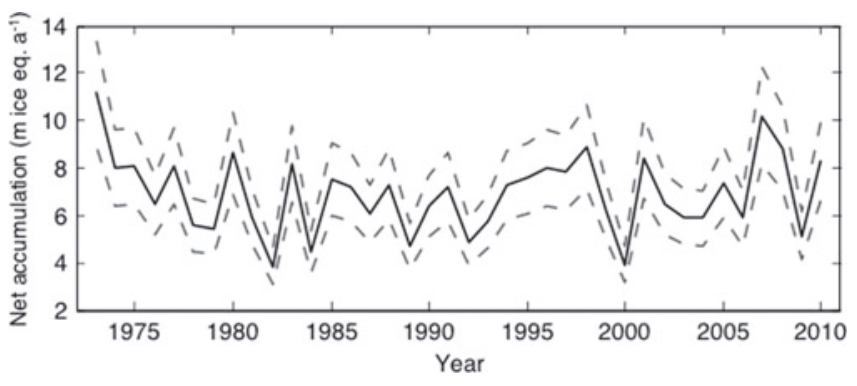

Fig. 10. Ice-flow-corrected annual accumulation, with a $\pm 12 \%$ uncertainty threshold marked by the gray dashed lines.

\section{RELATIONSHIP BETWEEN ACCUMULATION RATE AND REGIONAL PRECIPITATION}

Time series of annual snow accumulation developed from alpine ice-core records have been used previously as indicators of past climate variability. A central challenge to using ice-core records in this way, however, is that the accumulation rate at a specific high-altitude site may reflect only very regional climate, or even microclimatic conditions. Nevertheless, previous studies have had some success: the Mount Logan accumulation time series has been used to examine variability in the strength of the Aleutian low (e.g. Moore and others, 2003), while Rupper and others (2004) argued that the Mount Logan record could be meaningfully related to the large-scale precipitation variability for the largest winter storms. It is therefore of interest to examine the extent to which the Combatant Col record may similarly reflect regional or large-scale climate variability.

Comparison with both local precipitation records (locations marked in Fig. 1; Table 2) and large-scale climate reanalyses suggests that the Combatant Col record does meaningfully reflect regional-scale precipitation. We calculated the correlation between the annually averaged accumulation from Combatant Col and the precipitation rates from British Columbia weather stations (Environment

Table 2. Coordinates, elevation and record lengths for all Environment Canada weather stations used in precipitation-accumulation correlations

\begin{tabular}{|c|c|c|c|}
\hline Location & Coordinates & $\begin{array}{l}\text { Elevation } \\
\text { ma.s.I. }\end{array}$ & $\begin{array}{c}\text { Record length } \\
\text { (used in correlations) }\end{array}$ \\
\hline Port Hardy & $\begin{array}{c}50.68^{\circ} \mathrm{N} \\
127.37^{\circ} \mathrm{W}\end{array}$ & 21.6 & 1973-2009 \\
\hline Powell River & $\begin{array}{c}49.88^{\circ} \mathrm{N} \\
124.55^{\circ} \mathrm{W}\end{array}$ & 51.8 & 1973-2006 \\
\hline Campbell River & $\begin{array}{l}49.95^{\circ} \mathrm{N} \\
125.27^{\circ} \mathrm{W}\end{array}$ & 105.5 & 1973-2006 \\
\hline Tofino & $\begin{array}{c}49.08^{\circ} \mathrm{N} \\
125.77^{\circ} \mathrm{W}\end{array}$ & 24.5 & 1973-2006 \\
\hline Bella Coola & $\begin{array}{c}52.37^{\circ} \mathrm{N}, \\
126.69^{\circ} \mathrm{W}\end{array}$ & 18.3 & 1973-2002 \\
\hline Prince Rupert & $\begin{array}{l}54.29^{\circ} \mathrm{N} \\
130.44^{\circ} \mathrm{W}\end{array}$ & 35.4 & 1973-2005 \\
\hline Lilloet & $\begin{array}{c}50.67^{\circ} \mathrm{N} \\
121.92^{\circ} \mathrm{W}\end{array}$ & 198.1 & $1973-2000$ \\
\hline Tatlayoko & $\begin{array}{c}51.67^{\circ} \mathrm{N} \\
124.41^{\circ} \mathrm{W}\end{array}$ & 870 & 1973-97 \\
\hline
\end{tabular}




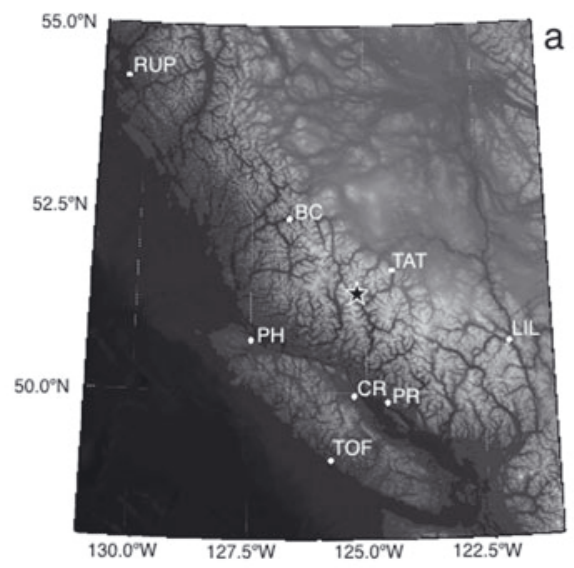

b
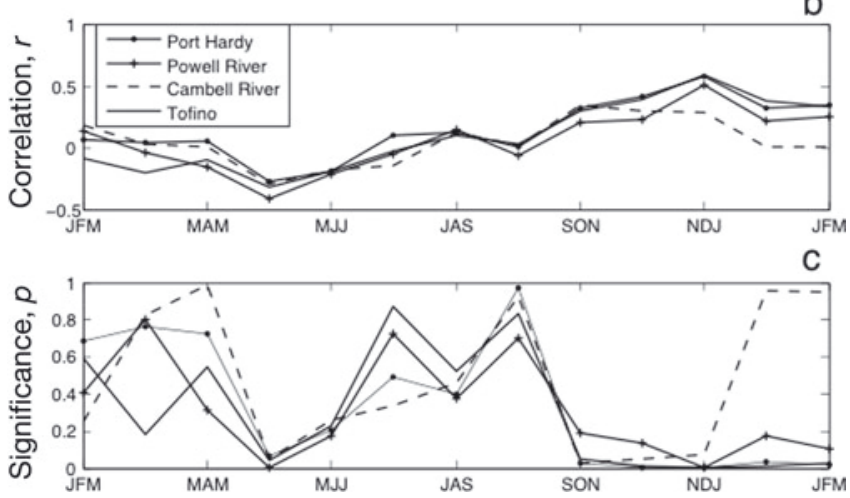

Fig. 11. Map (a) shows weather stations used for precipitation data: Port Hardy (PH), Campbell River (CR), Tofino (TOF), Powell River $(\mathrm{PR})$, Prince Rupert (RUP), Bella Coola (BC), Tatlayoko Lake (TAT) and Lillooet (LIL). Combatant Col is starred. (b) Correlation, $r$, between 1 year adjusted Combatant Col accumulation time series and seasonal averages of precipitation data from nearby coastal weather stations beginning \pm 6 months from JAS of 1973. JFM: January-March; MAM: March-May; MJJ: May-July; JAS: JulySeptember; SON: September-November; NDJ: November-January. (c) Significance levels, $p$, indicating that significance of positive correlations between Combatant Col accumulation and weatherstation precipitation data is maximized during winter months. Detailed correlation statistics are presented in Table 3.

Canada, 2011), using seasonal (3 month) averages for all seasons, starting in July (the nominal beginning of each accumulation year in the core), for lags of up to 1 year. We find that correlations are maximized with a lag of 1 year, and are significant at that lag $(p<0.05)$. Although a lag of 1 year is obviously not physically meaningful, this lies within the expected dating uncertainty for the core. Several lines of evidence argue the high correlations reflect a real, physically meaningful relationship between Combatant Col accumulation and regional precipitation. First, the maximum correlation occurs when the station averages are centered on the winter accumulation season, November-January. Second, more significant correlations are found with weather station precipitation records on the windward (west) side of the Coast Mountains, at Port Hardy, Tofino and Campbell River on Vancouver Island, and Powell River on the mainland. Stations east of the range's crest or further north (Tatlayoko, Lillooet, Bella Coola and Prince Rupert) show correlations in some seasons but are less consistent in timing and in general are less significant. The pattern of greater correlation with stations to the west is to be expected, because Mount Waddington clearly receives precipitation

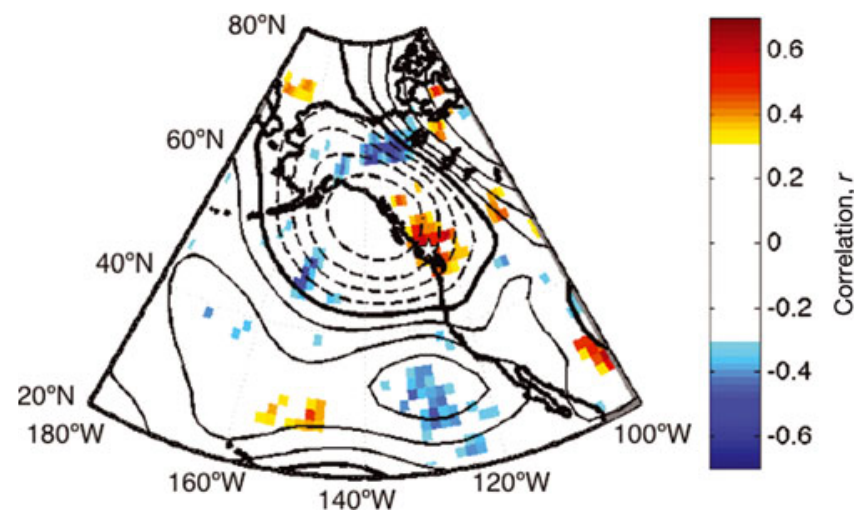

Fig. 12. Correlation between Combatant Col annual accumulation and ERA40/ERA-Interim annual precipitation and $500 \mathrm{hPa}$ geopotential heights (averaged July through June). Shading indicates correlation, $r$, with precipitation; areas of statistically significant correlation $(p<0.05)$ are colored. Contours (interval 0.1 , negative values dashed, zero contour bold, positive values solid) indicate correlation with $500 \mathrm{hPa}$ geopotential height; values $<-0.25$ and $>0.25$ are significant at $95 \%$. Combatant Col location is starred.

almost exclusively due to orographic effects as westerly storms encounter the Coast Mountains, rather than from easterly flow originating in the dry British Columbia interior.

We find that if we shorten the total length of the record by 1 year, by combining the annual accumulation total of two adjacent years - a reasonable possibility as annual stratigraphy in some years is not entirely unambiguous - significant correlations remain, but with zero lag. The most likely candidate pair of years is 2004 and 2005. The spring/ summer chemical peak originally selected as the lower/older boundary of year 2005 is ambiguous (see Fig. 5). This adjustment yields a very high accumulation rate estimate for 2005 (i.e. the $5.9 \mathrm{~m}$ in 2004 and $7.4 \mathrm{~m}$ in 2005 becomes $13.3 \mathrm{~m}$ ice eq. in 2005), in agreement with weather station precipitation data from coastal weather station sites southwest (upwind) of Combatant Col (e.g. Tofino; Environment Canada, 2011). Further, the seasonal correlation using this timescale remains maximized in November-January, consistent with the climatological maxima in both precipitation amount and precipitation variability (Fig. 11; Table 3).

In Figure 12, we compare the Combatant Col annual accumulation time series with large-scale precipitation and atmospheric circulation variability using annual precipitation and geopotential height data (averaged July-June) from the European Centre for Medium-Range Weather Forecasts (ECMWF) ERA40/ERA-Interim climate reanalysis data (Uppala and others, 2005; Dee and others, 2011). We find significance levels are high where expected: over Mount Waddington itself, and over Vancouver Island to the immediate west (Fig. 12a). Furthermore, the correlation pattern with both precipitation and $500 \mathrm{hPa}$ geopotential heights is consistent with our previous understanding of large-scale controls on precipitation variability in this region (Overland and Hiester, 1980). In particular, positive correlations with precipitation extend westward along the climatological trajectory of westerly wind, while there is a negative correlation with precipitation in coastal Alaska, similar to the characteristic south-north dipole pattern associated with the Pacific/North American pattern (Wallace and Gutzler, 1981). The correlation with $500 \mathrm{hPa}$ geopotential height is strongly negative (associated with 
Table 3. Correlation, $r$, and significance, $p$, between the annual mean Combatant Col accumulation time series (1973.5-2009.5), adjusted by 1 year as detailed in the text, and precipitation at Environment Canada weather stations for different 3 month averages (beginning March 1973) and annual mean (averaged July through June). MAM: March-May; MJJ: May-July; JAS: July-September; SON: September-November; NDJ: November-January; JFM: January-March. Bold numbers show where positive correlations are significant at better than $p<0.1$, with $p<0.05$ in bold italics

\begin{tabular}{|c|c|c|c|c|c|c|c|c|c|c|c|c|c|c|}
\hline \multirow[t]{2}{*}{ Location } & \multicolumn{2}{|c|}{ MAM } & \multicolumn{2}{|c|}{ MJJ } & \multicolumn{2}{|c|}{ JAS } & \multicolumn{2}{|c|}{ SON } & \multicolumn{2}{|c|}{ NDJ } & \multicolumn{2}{|c|}{ JFM } & \multicolumn{2}{|c|}{ Annual } \\
\hline & $r$ & $p$ & $r$ & $p$ & $r$ & $p$ & $r$ & $p$ & $r$ & $p$ & $r$ & $p$ & $r$ & $p$ \\
\hline $\begin{array}{l}\text { Port } \\
\text { Hardy }\end{array}$ & 0.05 & 0.73 & -0.19 & 0.21 & 0.13 & 0.40 & 0.32 & 0.03 & 0.57 & 0.00 & 0.34 & 0.02 & 0.59 & 0.00 \\
\hline $\begin{array}{l}\text { Powell } \\
\text { River }\end{array}$ & -0.16 & 0.32 & -0.21 & 0.18 & 0.14 & 0.38 & 0.20 & 0.19 & 0.50 & 0.00 & 0.25 & 0.10 & 0.41 & 0.01 \\
\hline $\begin{array}{l}\text { Campbell } \\
\text { River }\end{array}$ & 0.00 & 0.99 & -0.18 & 0.26 & 0.12 & 0.46 & 0.34 & 0.03 & 0.28 & 0.07 & 0.01 & 0.95 & 0.23 & 0.14 \\
\hline Tofino & -0.09 & 0.55 & -0.19 & 0.22 & 0.10 & 0.53 & 0.30 & 0.05 & 0.59 & 0.00 & 0.34 & 0.03 & 0.61 & 0.00 \\
\hline $\begin{array}{l}\text { Bella } \\
\text { Coola }\end{array}$ & 0.13 & 0.43 & 0.21 & 0.22 & -0.01 & 0.98 & 0.21 & 0.22 & 0.32 & 0.06 & -0.03 & 0.88 & 0.18 & 0.29 \\
\hline $\begin{array}{l}\text { Prince } \\
\text { Rupert }\end{array}$ & -0.01 & 0.94 & -0.08 & 0.60 & 0.08 & 0.62 & 0.04 & 0.80 & -0.10 & 0.53 & -0.06 & 0.70 & -0.06 & 0.72 \\
\hline Lillooet & -0.16 & 0.37 & -0.19 & 0.29 & -0.09 & 0.63 & 0.32 & 0.06 & 0.38 & 0.03 & 0.48 & 0.01 & 0.12 & 0.50 \\
\hline Tatlayoko & 0.44 & 0.01 & -0.08 & 0.67 & -0.35 & 0.05 & 0.04 & 0.82 & 0.43 & 0.02 & -0.02 & 0.93 & -0.17 & 0.38 \\
\hline
\end{tabular}

lower than average geopotential heights) over the Gulf of Alaska. This is a similar configuration of geopotential height to that associated with greater than average storminess and precipitation along the west coast of British Columbia (Rodionov and others, 2007).

These correlations are based on a relatively short record, only 37 years, while the ultimate goal of this ice-core project is to gain insight into regional conditions extending beyond the instrumental period. This should be achievable at Combatant Col, because the presence of ice in excess of 200 years of age near the bed is very likely based on observed depth-age relationship. A longer record should also allow for more precise dating, because the age of deeper ice is likely constrained by deposits from the Katmai (Alaska; 1912), Tambora (Indonesia; 1815) and other eruptions seen in the Eclipse Icefield and Mount Logan ice cores (Yalcin and others, 2007).

\section{CONCLUSIONS}

Retrieving ice-core paleoclimate records from temperate glaciers has been attempted only rarely, because it has often been observed that annual stratigraphy, critical to dating the records, will not be preserved. Our results from the Combatant $\mathrm{Col}$ ice core demonstrate that unambiguous seasonal stratigraphy can be preserved in visual and chemical records from temperate ice, provided that annual snow accumulation rates exceed the depth penetrated by summer surface meltwater. In addition to allowing for accurate dating, preserved chemical stratigraphy provides valuable information about the deposition of natural and anthropogenic aerosols at remote sites. The record of lead deposited at Combatant Col likely reflects a North American source since the 1970s, correlating well with North American leademission histories and with lead records from Greenland ice cores. This contrasts with the Asian source of lead deposited at Mount Logan, and illustrates the value of exploiting icecore records from mid-latitude sites, which clearly do not reflect the same atmospheric circulation as more northerly locations. Furthermore, based on its covariance with regional weather station and climate reanalysis data the accumulation time series from the Combatant Col ice core appears to meaningfully reflect regional-scale climate variability. These results suggest there is more potential than previously thought in exploring ice-core sites at midlatitudes where cold glaciers are uncommon. Although the high-accumulation criterion limits the age of ice preserved at depth in relatively shallow alpine glaciers, ice with an age of several hundred years is likely preserved at Combatant Col. Because of Combatant Col's location at the southern extreme of the dipole pattern in precipitation along the coast of northwestern North America (e.g. Bitz and Battisti, 1999), information from a deeper ice core at this site will add important spatial detail to the study of regional climate variability using existing records from Alaska and the Yukon.

\section{ACKNOWLEDGEMENTS}

We thank Beth Bergeron and Ice Drilling Design and Operations for expert drilling leadership, the King family and employees at White Saddle Air, Bluff Lake, British Columbia, and TC Trans trucking for an emergency ice-core freezer replacement. Field assistants were M. Bisiaux, N. Bowermann, K. Sterle, J. Theis, S. Schoenemann, A. McKee, M. Park, T. Hutchison, J. Brann and K. McConnell. $\mathrm{H}$. Roop assisted in planning field logistics, and helped process the core along with A. Gusmeroli. T.J. Fudge assisted in dating the core. We also thank the US National Ice Core Laboratory for sampling support, and technicians and students at the Desert Research Institute Ultra-Trace Chemistry Laboratory and Andrew Schauer and other staff at $\Delta^{*}$ IsoLab (University of Washington) for their analytical expertise. We thank E.D. Waddington, G. Roe, M. Winstrup and two anonymous reviewers for providing helpful comments on the manuscript. This project was supported by grants from the US National Science Foundation Paleoclimate Program, awards 0902240, 0902392, 0902734 and 0903124, and by the Western Canadian Cryospheric Network, funded by the Canadian Foundation for Climate and Atmospheric Sciences. 


\section{REFERENCES}

Bey I, Jacob DJ, Logan JA and Yantosca RM (2001) Asian chemical outflow to the Pacific in spring: origins, pathways, and budgets. J. Geophys. Res., 106(D19), 23 097-23 113 (doi: 10.1029/ 2001JD000806)

Bitz CC and Battisti DS (1999) Interannual to decadal variability in climate and the glacier mass balance in Washington, western Canada, and Alaska. J. Climate, 12(11), 3181-3196

Bowen GJ (2008) Spatial analysis of the intra-annual variation of precipitation isotope ratios and its climatological corollaries. J. Geophys. Res., 113(D5), D05113 (doi: 10.1029/ 2007JD009295)

Bretherton CS, Widmann M, Dymnikov VP, Wallace JM and Bladé I (1999) The effective number of spatial degrees of freedom of a time-varying field. J. Climate, 12(7), 1990-2009 (doi: 10.1175/ 1520-0442(1999)012<1990:TENOSD >2.0.CO;2)

Bulhöfer A and Rosman KJR (2001) Isotopic source signatures for atmospheric lead: the Northern Hemisphere. Geochim. Cosmochim. Acta, 65(11), 1727-1740 (doi: 10.1016/S00167037(00)00630-X)

Dansgaard W (1964) Stable isotopes in precipitation. Tellus, 16(4), 436-468

Dansgaard W and Johnsen SJ (1969) A flow model and a time scale for the ice core from Camp Century, Greenland. J. Glaciol., 8(53), 215-223

DeeDPand 35 others (2011) TheERA-Interim reanalysis: configuration andperformanceofthedataassimilationsystem.Q.J.R.Meteorol.Soc., 137(656),553-597(doi:10.1002/qj.828)

Environment Canada (2011) Canadian climate normals 19712000. National Climate Data and Information Archive, Fredericton, N.B. http://www.climate.weatheroffice.gc.ca

EPICA Community Members (2004) Eight glacial cycles from an Antarctic ice core. Nature, 429(6992), 623-628 (doi: 10.1038/ nature02599)

Fisher DA and 12 others (1998) Penny Ice Cap cores, Baffin Island, Canada, and the Wisconsinan Foxe Dome connection: two states of Hudson Bay ice cover. Science, 279(5351), 692-695

Fisher D and 16 others (2008) The Mt Logan Holocenelate Wisconsinan isotope record: tropical Pacific-Yukon connections. Holocene, 18(5), 667-677 (doi: 10.1177/ 0959683608092236)

Gonfiantini R (1978) Standards for stable isotope measurements in natural compounds. Nature, 271(5645), 534-536 (doi: 10.1038/ 271534a0)

Ice Drilling Design and Operations (IDDO) (2011) Long range drilling technology plan. Ice Drilling Program Office, Hanover, $\mathrm{NH}$. http://icedrill.org/documents/view.shtml?id=272

Jaffe D, McKendry I, Anderson T and Price H (2003) Six 'new' episodes of trans-Pacific transport of air pollutants. Atmos. Environ., 37(3), 391-404 (doi: 10.1016/S1352-2310(02) 00862-2)

Kaspari S and 7 others (2009) A high-resolution record of atmospheric dust composition and variability since A.D. 1650 from a Mount Everest ice core. J. Climate, 22(14), 3910-3925 (doi: 10.1175/2009JCLI2518.1)

Koerner RM (1997) Some comments on climatic reconstructions from ice cores drilled in areas of high melt. J. Glaciol., 43(143), 90-97

Legrand M and Mayewski P (1997) Glaciochemistry of polar ice cores: a review. Rev. Geophys., 35(3), 219-243 (doi: 10.1029/ 96RG03527)

Lewis TJ, Jessop AM and Judge AS (1985) Heat flux measurements in southwestern British Columbia: the thermal consequences of plate tectonics. Can. J. Earth Sci., 22(9), 1262-1273 (doi: 10.1139/e85-131)

Lliboutry L (1971) Permeability, brine content and temperature of temperate ice. J. Glaciol., 10(58), 15-29

McConnell JR and Edwards R (2008) Coal burning leaves toxic heavy metal legacy in the Arctic. Proc. Natl Acad. Sci. USA (PNAS), 105(34), 12 140-12 144 (doi: 10.1073/pnas.0803564105)
McConnell JR, Lamorey GW, Lambert SW and Taylor KC (2002) Continuous ice-core chemical analyses using inductively coupled plasma mass spectrometry. Environ. Sci. Technol., 36(1), 7-11 (doi: 10.1021/es011088z)

McConnell JR and 9 others (2007) 20th-century industrial black carbon emissions altered Arctic climate forcing. Science, 317(5843), 1381-1384 (doi: 10.1126/science.1144856)

McGwire KC and 6 others (2008) An integrated system for optical imaging of ice cores. Cold Reg. Sci. Technol., 53(2), 216-228 (doi: 10.1016/j.coldregions.2007.08.007)

Merrill JT, Uematsu M and Bleck R (1989) Meteorological analysis of long range transport of mineral aerosols over the north Pacific. J. Geophys. Res., 94(D6), 8584-8598 (doi: 10.1029/ JD094iD06p08584)

Moore GWK, Alverson K and Holdsworth G (2003) The impact that elevation has on the ENSO signal in precipitation records from the Gulf of Alaska region. Climatic Change, 59(1-2), 101-121 (doi: 10.1023/A:1024423925161)

Moore JC, Grinsted A, Kekonen T and Pohjola V (2005) Separation of melting and environmental signals in an ice core with seasonal melt. Geophys. Res. Lett., 32(10), L10501 (doi: 10.1029/2005GL023039)

Moran T and Marshall S (2009) The effects of meltwater percolation on the seasonal isotopic signals in an Arctic snowpack. J. Glaciol., 55(194), 1012-1024 (doi: 10.3189/ 002214309790794896)

Naftz DL and 7 others (1996) Little Ice Age evidence from a southcentral North American ice core, U.S.A. Arct. Alp. Res., 28(1), 35-41

Naftz DL and 6 others (2002) Ice core evidence of rapid air temperature increases since 1960 in alpine areas of the Wind River Range, Wyoming, United States. J. Geophys. Res., 107(D13), 4171 (doi: 10.1029/2001JD000621)

National Climatic Data Center (NCDC) (2008) Global measured extremes of temperature and precipitation. US Department of Commerce http://www.ncdc.noaa.gov/oa/climate/globalextremes.html (accessed 1 March 2012)

Osterberg E and 10 others (2008) Ice core record of rising lead pollution in the North Pacific atmosphere. Geophys. Res. Lett., 35(5), L05810 (doi: 10.1029/2007GL032680)

Overland JE and Hiester TR (1980) Development of a synoptic climatology for the northeast Gulf of Alaska. J. Appl. Meteorol., 19(1), 1-14 (doi: 10.1175/1520-0450(1980)019<0001: DOASCF $>2.0 . C O ; 2)$

Paterson WSB (1994) The physics of glaciers, 3rd edn. Elsevier, Oxford

Pfeffer WT and Humphrey NF (1996) Determination of timing and location of water movement and ice-layer formation by temperature measurements in sub-freezing snow. J. Glaciol., 42(141), 292-304

Pohjola V and 7 others (2002) Effect of periodic melting on geochemical and isotopic signals in an ice core on Lomonosovfonna, Svalbard. J. Geophys. Res., 107(D4), 4036 (doi: 10.1029/2000JD000149)

Preunkert S, Wagenbach D, Legrand M and Vincent C (2000) Col du Dôme (Mt Blanc Massif, French Alps) suitability for ice core studies in relation with past atmospheric chemistry over Europe. Tellus, 52B(3), 993-1012

Rodionov SN, Bond NA and Overland JE (2007) The Aleutian Low, storm tracks, and winter climate variability in the Bering Sea. Deep-Sea Res. II, 54(23-26), 2560-2577 (doi: 10.1016/j.dsr2. 2007.08.002)

Rosman KJR, Chisholm W, Boutron CF, Candelone JP and Hong S (1994) Isotopic evidence to account for changes in the concentration of lead in Greenland snow between 1960 and 1988. Geochim. Cosmochim. Acta, 58(15), 3265-3269

Rupper S, Steig EJ and Roe G (2004) The relationship between snow accumulation at Mt. Logan, Yukon, Canada, and climate variability in the North Pacific. J. Climate, 17(24), 4724-4739 (doi: 10.1175/JCLI-3202.1) 
Schotterer U, Fröhlich K, Gäggeler HW, Sandjordj S and Stichler W (1997) Isotope records from Mongolian and Alpine ice cores as climate indicators. Climatic Change, 36(3-4), 519-530

Schotterer U, Stichler W and Ginot P (2004) The influence of postdepositional effects on ice core studies: examples from the Alps, Andes, and Altai. In Cecil LD, Green JR and Thompson LG eds. Earth paleoenvironments: records preserved in mid- and lowlatitude glaciers. Kluwer Academic, Dordrecht, etc., 39-60

Schwikowski M, Brütsch S, Gäggeler HW and Schotterer U (1999) A high-resolution air chemistry record from an Alpine ice core: Fiescherhorn glacier, Swiss Alps. J. Geophys. Res., 104(D11), 13 709-13 719

Shiraiwa T and 7 others (2003) Ice core drilling at King Col, Mount Logan 2002. Bull. Glaciol. Res., 20, 57-63

Steig EJ (2004) Foreword. In Cecil LD, Green JR and Thompson LG eds. Earth paleoenvironments: records preserved in mid- and low-latitude glaciers. Kluwer Academic, Dordrecht, xix-xxii

Taylor KC and 12 others (1997) The Holocene-Younger Dryas transition recorded at Summit, Greenland. Science, 278(5340), $825-827$

Thevenon F, Anselmetti FS, Bernasconi SM and Schwikowski M (2009) Mineral dust and elemental black carbon records from an Alpine ice core (Colle Gnifetti glacier) over the last millennium. J. Geophys. Res., 114(D17), D17102 (doi: 10.1029/ 2008JD011490)

Thompson LG (2000) Ice core evidence for climate change in the Tropics: implications for our future. Quat. Sci. Rev., 19(1-5), 19-35 (doi: 10.1016/S0277-3791(99)00052-9)

Thompson LG (2004) High altitude, mid- and low latitude ice core records: implications for our future. In Cecil LD, Green JR and Thompson LG eds. Earth paleoenvironments: records preserved in mid- and low-latitude glaciers. Kluwer Academic, Dordrecht, 3-15

Thompson LG and 7 others (1995) Late glacial stage and Holocene tropical ice core records from Huascarán, Peru. Science, 269(5220), 46-50 (doi: 10.1126/science.269.5220.46)

Uppala SM and 45 others (2005) The ERA-40 re-analysis. Q. J. $R$. Meteorol. Soc., 131(612), 2961-3212 (doi: 10.1256/qj.04.176)

Urmann D (2009) Decadal scale climate variability during the last millennium as recorded by the Bona-Churchill and Quelccaya ice cores. (PhD thesis, University of Ohio)

Vincent C, Vallon M, Pinglot JF, Funk M and Reynaud L (1997) Snow accumulation and ice flow at Dôme du Goûter (4300 m), Mont Blanc, French Alps. J. Glaciol., 43(145), 513-521

Waddington ED, Bolzan JF and Alley RB (2001) Potential for stratigraphic folding near ice-sheet centers. J. Glaciol., 47(159), 639-648 (doi: 10.3189/172756501781831756)

Wallace JM and Gutzler DS (1981) Teleconnections in the geopotential height field during the Northern Hemisphere winter. Mon. Weather Rev., 109(4), 784-812 (doi: 10.1175/ 1520-0493(1981)109<0784:TITGHF>2.0.CO;2)

Yalcin K and Wake CP (2001) Anthropogenic signals recorded in an ice core from Eclipse Icefield, Yukon Territory, Canada. Geophys. Res. Lett., 28(23), 4487-4490 (doi: 10.1029/2001GL013037)

Yalcin K, Wake CP, Kreutz KJ, Germani MS and Whitlow SI (2007) Ice core paleovolcanic records from the St. Elias Mountains, Yukon, Canada. J. Geophys. Res., 112(D8), D08102 (doi: 10.1029/ 2006JD007497)

Yasunari TJ and 7 others (2007) Intra-annual variations in atmospheric dust and tritium in the North Pacific region detected from an ice core from Mount Wrangell, Alaska. J. Geophys. Res., 112(D10), D10208 (doi: 10.1029/2006JD008121) 